\title{
A Great Difference Between Sedentary Subspecies of Laniarius atroflavus Shelley, 1887 Suggests on the Base of Molecular Data that Laniarius atroflavus and Laniarius craterum are Two Separate Species
}

\author{
Billy Nguembock ${ }^{1,2, *}$
}

\author{
${ }^{1}$ Laboratoire de Zoologie, Département de Biologie et Physiologie Animales, Université de Yaoundé I, BP 812 Yaoundé, \\ Cameroun; ${ }^{2}$ Département de Sciences Biologiques, Université de Montréal, C.P. 6128, succursale du Centre-ville, Mon- \\ tréal, QC, H3C 3J7, Canada
}

\begin{abstract}
Laniarius atroflavus is a sedentary member of the bush-shrike radiation (family Malaconotidae) and in our first paper, it appeared with strong divergence between its two subspecies. To confirm this divergence and leaning partially on our first obtained results, we investigated a genetic variation of the individuals of Laniarius atroflavus atroflavus (West Africa) and Laniarius atroflavus craterum (West Africa). For the genetic variation, we use two mitochondrial genes (ATPase6 and ND2) to calculate their genetic distances within the Laniarius ingroup and to explore their mutational differentiation. With our ATPase6 and ND2, a genetic distance of $1.66 \%$ and $2.14 \%$ has been respectively estimated between individuals of Laniarius atroflavus atroflavus (Cameroon Mountain) and Laniarius atroflavus craterum (Manenguba Mountain) whereas it was, for the same markers, of $0 \%$ and $0.57 \%$ respectively between specimens of Laniarius atroflavus craterum only caught in diverse parts of the Manenguba Mountain. For the mutational differentiation, a total of 34 different molecular characters have been observed with the two markers investigated between these two subspecies. Leaning on some dating results, it appears that Laniarius atroflavus atroflavus diverged from Laniarius atroflavus craterum during the Quaternary period and these dates correspond remarkably with those suggested for several polyphased volcanic activities noted in the Cameroon Volcanic Line. For these separate sedentary birds which are marked by their clinal size variation, measures of their wings as well as the variation of the color of their breast and belly, a possible secondary contact will certainly lead to reinforcement. Thus, we suggest resurrecting names Laniarius atroflavus Shelley, 1887 and Laniarius craterum Bates, 1926 for individuals of the populations hitherto referred as Laniarius atroflavus atroflavus and Laniarius atroflavus craterum respectively.
\end{abstract}

Keywords: Bush-shrike radiation, Cameroon volcanic line, divergence, genetic distance, mutational differentiation, Quaternary period, reinforcement.

\section{INTRODUCTION}

Laniarius is one of the diverse lineages within the avian bush-shrike radiation, the family Malaconotidae $[1,2]$. Before our first molecular study concerning this genus [1], relationships of their members were poorly known and groupings were realized on the basis of plumage colours [3-6]. Since our study, their monophyly is strongly supported and relationships of their members are clearly known [1]. Otherwise, this study permitted to note that within the Laniarius group the variation in pigments and patterns does not follow phylogenetic lineages and the plumage coloration appears as an unreliable morphological character for defining species and species groups [1]. According to [2], Laniarius comprises of twenty-one (21) species among these, Laniarius atroflavus.

The Yellow-breasted Boubou is often described as a monotypic Boubou which has a very restricted geographic

\footnotetext{
*Address correspondence to this author at the Phylogenetician and Biogeographer of the African Passeriformes, Department of Animal Biology and Physiology, Faculty of Sciences, University of Yaounde I, P.O. Box 812 Yaounde, Republic of Cameroon; Tel: 00 (237) 941442 94; Fax: 00 (237) 222353 86; Email: billyngue@yahoo.fr
}

range. It is a sedentary resident which lives only in the West of Africa; thus Laniarius atroflavus is found only in Cameroon and Nigeria (see Figs. 1 and 2). Generally, it lives naturally in tropical and subtropical moist montane forests or moist shrubland as well as in tropical and subtropical high altitude shrubland even if sometimes it can be found in wetlands like permanent rivers, streams and creeks as well as in tropical and subtropical heavily degraded forest $[3,6]$.

According to [2], Laniarius atroflavus is a monotypic species but for [7], this species is represented by two subspecies, Laniarius atroflavus atroflavus Shelley, 1887 and Laniarius atroflavus craterum Bates, 1926. And as [7], this species is usually known to have at least two races in Cameroon with a clinal size variation, $L$. a. craterum being slightly greater than L. a. atroflavus. Laniarius atroflavus atroflavus is thus only distributed to Cameroon Mountain (West Cameroon) while Laniarius atroflavus craterum is distributed from Manenguba Mountain to Bamenda Highlands, Obudu Plateau, Mambilla Plateau and Chappal Hendu (West Cameroon and South East of Nigeria) [2, 3,6].

Before our study [1] and according to some authors such as [3], Laniarius atroflavus was included in the 


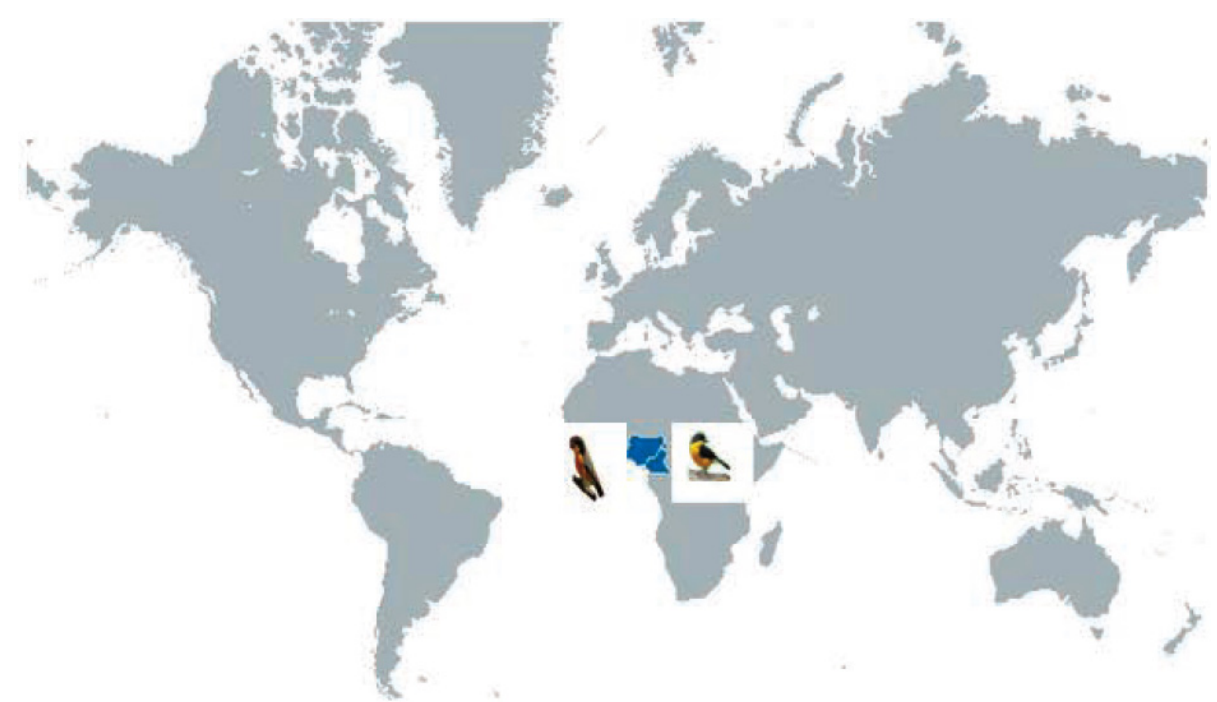

Fig. (1). Distribution of the Yellow-breasted Boubou. This map shows that the Yellow-breasted Boubou has a very restricted geographic range and it found only in Cameroon and Nigeria.
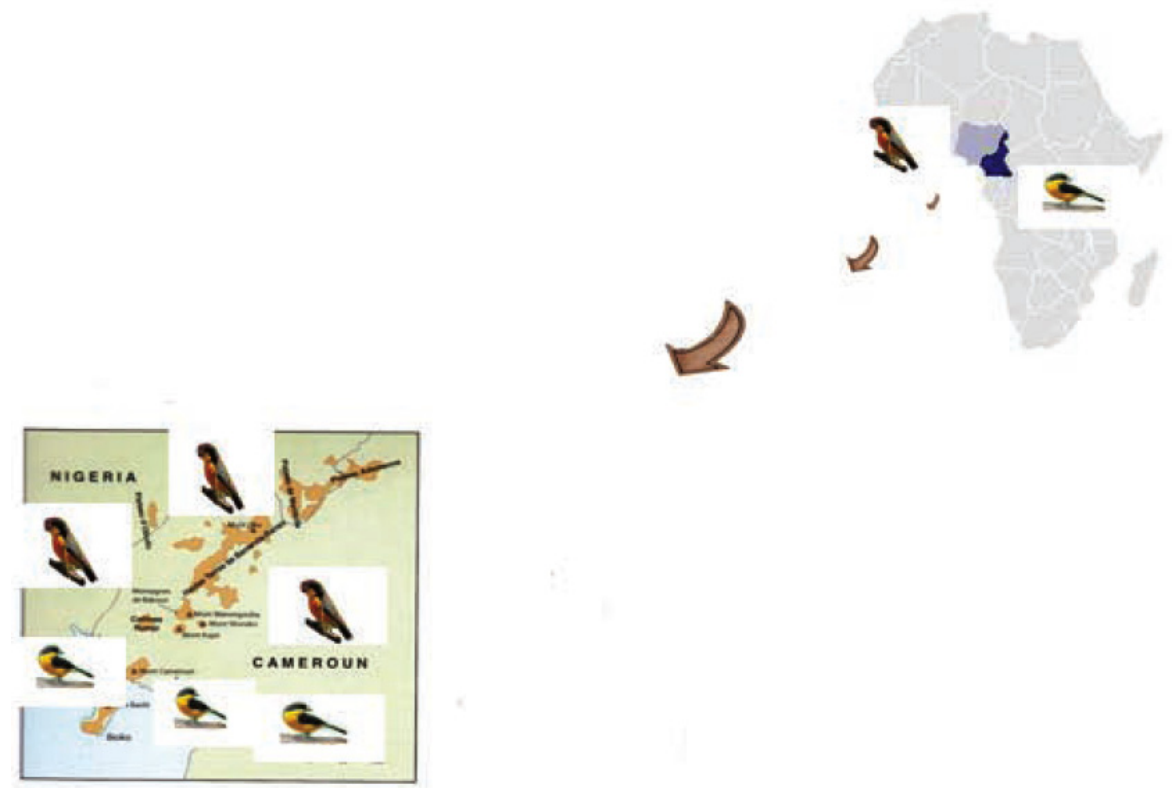

Fig. (2). Distribution of the Yellow-breasted Boubou through the Cameroon Volcanic Line. Laniarius atroflavus is restricted to Cameroon Mountain whereas Laniarius craterum is found from Manenguba Mountain to Bamenda Highlands (Oku Mountain) until South East of Nigeria.

barbarus superspecies with L. mufumbiri, L. barbarus, $L$. ruficeps and L. atrococcineus; but our study did not confirm this superspecies even if it supported the closed relation with L. mufumbiri [1]. In this study concerning the genus Laniarius [1], we had included the two subspecies of Laniarius atroflavus, L. a. atroflavus and L. a. craterum. Oddly, these two subspecies showed a deep divergence which is strongly supported in all our protein-coding genes ATPase6 and ND2 as well as our combined dataset with a high bootstrap (see [1]).

The type subspecies of the species Laniarius atroflavus Shelley, 1887 is Laniarius atroflavus atroflavus which was initially described as Laniarius atroflavus Shelley, 1887. And this species, according to authors, includes two (2) subspecies or two races which in principle have usually a differ- ent size. The second subspecies of Laniarius atroflavus is Laniarius atroflavus craterum Bates, 1926 which has been described as such and which has a restricted geographic range (see Figs. 1 and 2).

Leaning partially on our first obtained results concerning the genus Laniarius [1], in this study which includes the type subspecies of the species Laniarius atroflavus Shelley, 1887, we investigate a genetic variation of the two subspecies of Laniarius atroflavus caught in two places in West Africa (Cameroon Mountain and Manenguba Mountain). For this, we used two mitochondrial protein-coding genes evolving rapidly (ATPase6 and ND2) in order to assess their real differential genetic structure and to provide more information about these two sedentary subspecies of the Yellow-breasted Boubou which firmly live now in isolated biotopes. 


\section{MATERIALS AND METHODS}

\section{MATERIALS}

For the taxon sampling, we keep the same biological material already used in our first publication [1]. And for the species taxonomy, we will especially refer to our last study [1] as well as [7].

\section{METHODS}

\section{Genetic Distances of the Two Subspecies of the Yellow- breasted Boubou}

To examine genetic distances between these two subspecies, we used nucleotide sequences of two mitochondrial genes (ATPase6 and ND2) and we selected as model "Number of differences" for estimates of their genetic distances using MEGA v3.1 [8]. For this, we used the same taxa for which Genbank accession numbers have already been published in our first study for a total of Operational Taxonomic Units of 35 (ND2) and 37 (ATPase6) (Table 1).

\section{Mutational Differentiation Between the Two Subspecies of the Yellow-Breasted Boubou}

In order to explore main kinds of mutations between these two subspecies, we considered to compare nucleotide sequences of their molecular markers. For this, we mainly used contigs of the sequences of the two mitochondrial genes (ATPase6 and ND2) which were aligned using the algorithm in Sequencher 3.1 [9]; for each molecular marker, we compared nucleotide sequences of these two subspecies in order to find diverse kinds of mutations.

\section{Phylogenetic Analysis}

To examine phylogenetic relationships of these two subspecies of Laniarius atroflavus, we used same methods (Maximum Likelihood and Bayesian Inference). As results are same, in this present study we will lean on trees already obtained in our first study [1] in order to analyze their relationship as well as their closed relation with other ingroup taxa.

\section{RESULTS}

\section{Genetic Distances Results Between these Two Subspecies}

Results of the genetic distances are presented in Table 2. According to these estimates, the subspecies Laniarius atroflavus atroflavus appears different to the subspecies Lanairius atroflavus craterum. Thus, with the protein-coding gene ND2, the genetic distance obtained between these two subspecies was of $2.14 \%$ (Table 2). With the ATPase 6 gene, the genetic distance got between $L$. a. atroflavus and $L$. $a$. craterum was of $1.66 \%$ (Table 2). In the same time, we noted that genetic distances between specimens of $L$. $a$. craterum caught in diverse parts of the Manenguba Mountain estimated with protein-coding genes ATPase6 and ND2 were only of $0 \%$ and $0.57 \%$, respectively (see Table 2 ).

\section{Mutational Differentiation Results Between these Two Subspecies}

Results of the mutational differentiation are presented in Tables 3a and $\mathbf{3 b}$ and we note that only our mitochondrial genome permitted to observe the mutational differentiation between these two subspecies. According to these tables, the subspecies Laniarius atroflavus atroflavus presents several different molecular characters (substitution mutations) comparatively to $L$. a. craterum. With the two mitochondrial genes investigated, a total of 34 different molecular characters have been observed between these two subspecies of Laniarius atroflavus (Tables $\mathbf{3 a}$ and $\mathbf{3 b}$ ). Thus, with the protein-coding gene ATPase6, we noted 16 different molecular characters between these two subspecies (see Table 3a). With the ND2 gene, 18 molecular characters have been retrieved different between $L$. a. atroflavus and L. a. craterum (Table 3b). In our tables, we indicate accurately the number of substitution position such as observed in the Laniarius alignment of the two mitochondrial genes (Tables 3a and 3b).

\section{Phylogenetic Results}

As in our last publication concerning the genus Laniarius [1], Laniarius atroflavus appeared moderately close to Laniarius mufumbiri only with our combined dataset but not with our ND2 and ATPase6 datasets (Figs. 3, 4 and 5). Leaning on this publication [1], a relationship between subspecies Laniarius atroflavus atroflavus (Cameroon Mountain) and Laniarius atroflavus craterum (Manenguba Mountain) was strongly supported with high bootstrap values (PP 1.00 and PhyML bootstrap values 100) (Figs. 3, 4 and 5). But especially, all our phylograms with the two individual markers used as well as our concatenated dataset showed that Laniarius atroflavus atroflavus presents a very great divergence in relation to Laniarius atroflavus craterum (Figs. 3, 4 and 5). This divergence was strongly supported with high bootstrap values (PP 1.00 and PhyML bootstrap values 100). In this study, pictures of these two subspecies (L. a. atroflavus and $L$. a. craterum) clearly seem to confirm this strong divergence to their size variation as well as their general coloration (Figs. 3, 4 and 5). We note that our nuclear marker used (BRM intron15) did not resolve the relationship between subspecies Laniarius atroflavus atroflavus and Laniarius atroflavus craterum (tree not shown).

\section{DISCUSSION}

Several phylogenetic aspects of the genus Laniarius are already discussed in our last publication (see [1]). In this paper, we will focus on geological (plate tectonics) changes occurred in the CVL and subsequently their potential results on the diversification as well as the process of speciation of the endemic Yellow-breasted Boubou.

\section{Geological Changes within the Laniarius atroflavus Geo- graphic Range}

Some geological events and paleomagnetic studies which are widely documented permit to know now that the CVL has been submitted to a polyphased volcanic activity since the Paleogene period after the distension of the African plate during the Cenozoic era and which would have separated the Cameroonian Highlands Forests and the East African Highlands Forests [10-17]. Only, the origin of the CVL is more controversial and many hypotheses have been developed [16, 18-22]. 
Table 1. Operational Taxonomic Units (OTUs) used to estimate directly genetic distances within the Laniarius ingroup between subspecies of the species Laniarius atroflavus and to explore mutational differentiation after making contigs between these two subspecies. Genbank accession numbers of these OTUs have been already published in our first publication concerning this genus.

\begin{tabular}{|c|c|c|c|c|}
\hline \multicolumn{5}{|l|}{ Ingroup } \\
\hline L. aethiopicus ambiguus & Tanzania & ZMUC 116804 & EU328354 & EU554456 \\
\hline L. aethiopicus ambiguus & Kenya & ZMUC 116798 & EU328355 & EU554493 \\
\hline L. aethiopicus ambiguus & Kenya & ZMUC 124202 & EU328370 & EU554472 \\
\hline L. aethiopicus erlangeri & Somalia & MNHN CG 1964-1416 & EU328368 & EU554471 \\
\hline L. aethiopicus major & Chad & MNHN CG 1979-385 & EU328380 & EU554483 \\
\hline L. aethiopicus sublacteus & Tanzania & FMNH 356738 & EU328362 & EU554464 \\
\hline L. atrococcineus & South Africa & MNHN CG 1979-1389 & - & EU554486 \\
\hline L. atrococcineus & South Africa & ВH09819 & EU328388 & EU554492 \\
\hline L. atroflavus atroflavus & Cameroon & MNHN 40-2 & EU328365 & EU554467 \\
\hline L. atroflavus craterum & Cameroon & MNHN 40-1 & EU328364 & EU554466 \\
\hline L. atroflavus craterum & Cameroon & MNHN 40-30 & EU328383 & EU554487 \\
\hline L. barbarus barbarus & Senegal & MNHN CG 1968-911 & EU328367 & EU554469 \\
\hline L. ferrugineus savensis & South Africa & MNHN CG1981-83 & EU328377 & EU554480 \\
\hline L. fuelleborni fuelleborni & Tanzania & ZMUC 118836 & EU328356 & EU554457 \\
\hline L. fuelleborni fuelleborni & Tanzania & ZMUC 120597 & EU328357 & EU554458 \\
\hline L. funebris degener & Kenya & ZMUC 124145 & EU328358 & EU554459 \\
\hline L. leucorhynchus & Gabon & MNHN CG 1983-804 & - & EU554470 \\
\hline L. leucorhynchus & $\mathrm{RCA}$ & MNHN CG 1983-61 & - & EU554481 \\
\hline L. liberatus & Somalia & ZMUC 118877 & EU328359 & EU554460 \\
\hline L. luehderi castaneiceps & Uganda & ZMUC 119044 & AY529958 & EU554461 \\
\hline L. luehderi luehderi & Uganda & FMNH 355504 & EU328363 & EU554465 \\
\hline L. luehderi luehderi & Gabon & MNHN CG 1983-816 & EU328366 & EU554468 \\
\hline L. luehderi luhderi & Tanzania & ZMUC 135292 & EU328374 & EU554476 \\
\hline L. mufumbiri & Tanzania & $\mathrm{RB} 1560$ & EU328360 & EU554462 \\
\hline L. poensis camerunensis & Cameroon & MNHN CG 1982-TEZA & EU328382 & EU554485 \\
\hline
\end{tabular}


(Table 1) contd....

\begin{tabular}{|c|c|c|c|c|}
\hline Taxon & Country & Voucher Sample & ND2 & ATPase6 \\
\hline \hline L. poensis holomelas & Burundi & MNHN CG 2000-135 & EU328379 & EU554482 \\
\hline L. ruficeps rufinuchalis & Kenya & - & EU328378 & EU554488 \\
\hline L. turatii & Guinea & MNHN 40-32 & EU328384 & EU328385 \\
\hline L. turatii & Guinea & MNHN 40-33 & EU54489 \\
\hline
\end{tabular}

Table 2. Estimates of the number of differences (values in \%) obtained from the ADN mitochondrial among representatives of the Laniarius atroflavus species collected in several African forests following a "number of differences" model implemented in MEGA v.3.1.

\begin{tabular}{|l|c|}
\hline & ATPase6 \\
\hline \hline $\begin{array}{l}\text { Nucleotide: number of differences between L. atroflavus atroflavus (Cameroon Mountain)/L. atroflavus } \\
\text { craterum (Manenguba Mountain) }\end{array}$ & $1.66 \%$ \\
\hline $\begin{array}{l}\text { Nucleotide: number of differences between L. atroflavus craterum (one part of Manenguba Mountain)/ } \\
\text { L. atroflavus craterum (another part of Manenguba Mountain) }\end{array}$ & $0 \%$ \\
\hline
\end{tabular}

*: We used our largest Laniarius ingroup [1]

Table 3a. Molecular characters (substitution mutations) observed in the alignment of ATPase6 sequences among representatives of the Laniarius atroflavus species collected in several African forests.

Different Molecular Characters Between Laniarius atroflavus atroflavus* and L. a. craterum** (Number of substitution position in the Laniarius alignment of ATPase6 sequences)

*: Sequence EU554467 already published in Genbank [1]

**: Sequence EU554466 already published in Genbank [1]

Table 3b. Molecular characters (substitution mutations) observed in the alignment of ND2 sequences among representatives of the Laniarius atroflavus species collected in several African forests.

Different Molecular Characters Between Laniarius atroflavus atroflavus* and L. a. craterum** (Number of substitution position in the Laniarius alignment of ND2 sequences)

Transition A-G

$\mathrm{N}^{\circ} 354, \mathrm{~N}^{\circ} 360, \mathrm{~N}^{\circ} 369, \mathrm{~N}^{\circ} 621, \mathrm{~N}^{\circ} 637, \mathrm{~N}^{\circ} 642, \mathrm{~N}^{\circ} 738, \mathrm{~N}^{\circ} 807, \mathrm{~N}^{\circ} 912, \mathrm{~N}^{\circ} 961, \mathrm{~N}^{\circ} 979, \mathrm{~N}^{\circ} 993, \mathrm{~N}^{\circ} 1008$

Transition C-T

$\mathrm{N}^{\circ} 345, \mathrm{~N}^{\circ} 374, \mathrm{~N}^{\circ} 579, \mathrm{~N}^{\circ} 729$

Transversion A-T

$\mathrm{N}^{\circ} 938$

Total of molecular characters between races L. a. atroflavus and L. a. craterum

*: Sequence EU328365 already published in Genbank [1]

**: Sequence EU328364 already published in Genbank [1]
Total of Different Molecular Characters Observed for Each Kind of Substitution
4

1

18 


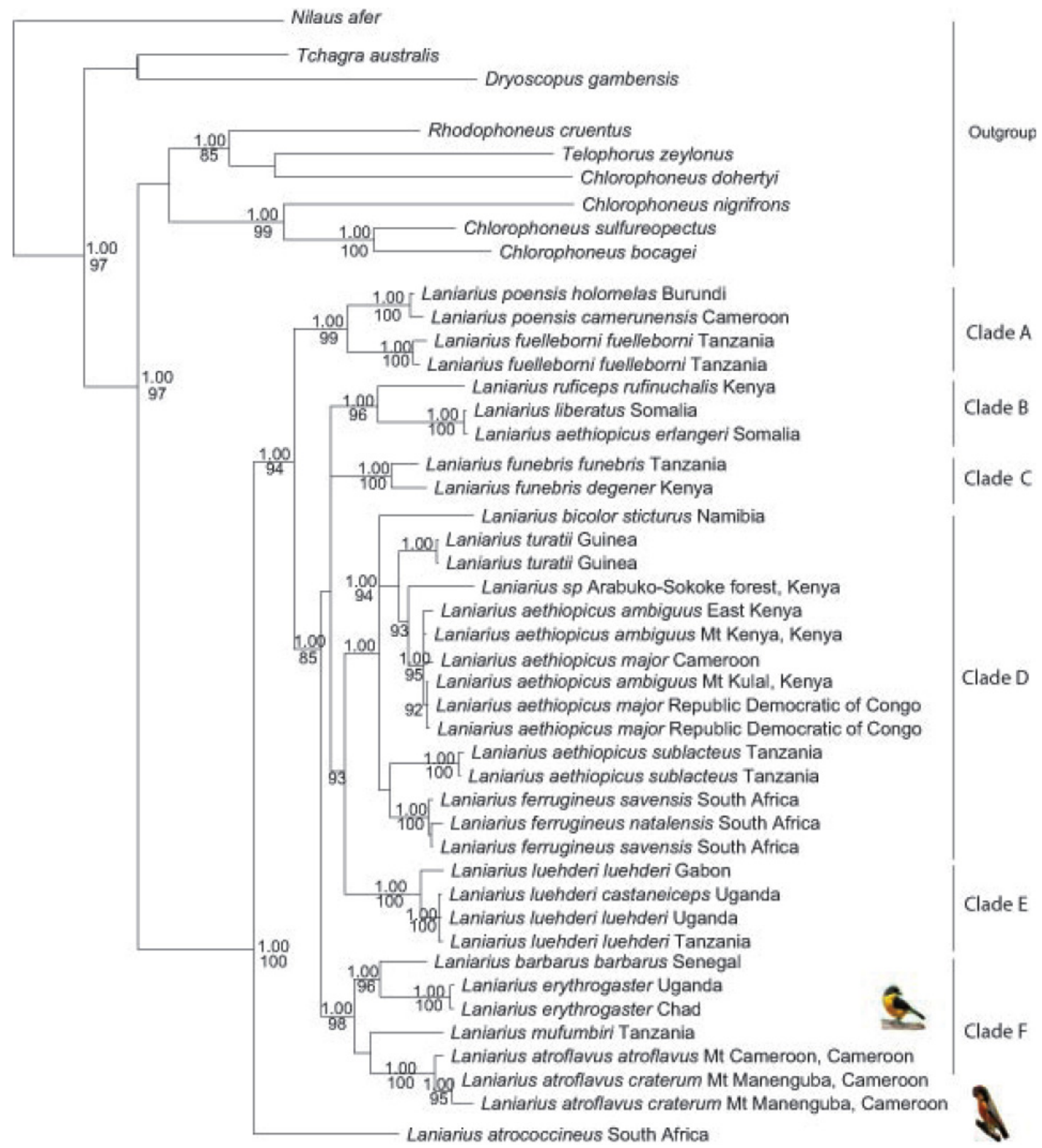

Fig. (3). Pictures of Laniarius atroflavus and Laniarius craterum on the ND2 tree obtained in [1] confirming the strong divergence between individuals of Cameroon Mountain and Manenguba Mountain.

Thus, the Manenguba Mountain is a volcanic complex which has been built for one part during the Cenozoic era and for another part during the Quaternary period whereas the most part of the Cameroon Mountain would have mainly been built by several volcanic activities during the Cenozoic era $[12,15,17]$.

\section{Diversification of the Species Laniarius atroflavus}

According to our unpublished dating results concerning the family Malaconotidae [23] as well as [24], the diversification of the genus Laniarius from the genus Chlorophoneus took place during the Miocene epoch and this time period appeared older than the Quaternary period estimated for the separation between Laniarius atroflavus atroflavus and Laniarius atroflavus craterum (Billy Nguembock, personal PhD unpublished results [23]). These putative dating results correspond remarkably with those suggested for several volcanic activities noted in the CVL $[12,15,17]$. Otherwise, we note a great difference on the CVL between the position of the Cameroon Mountain (down of the CVL) in relation to the position of the Manenguba Mountain (more near to Bamenda Highlands) (see Fig. 2). 


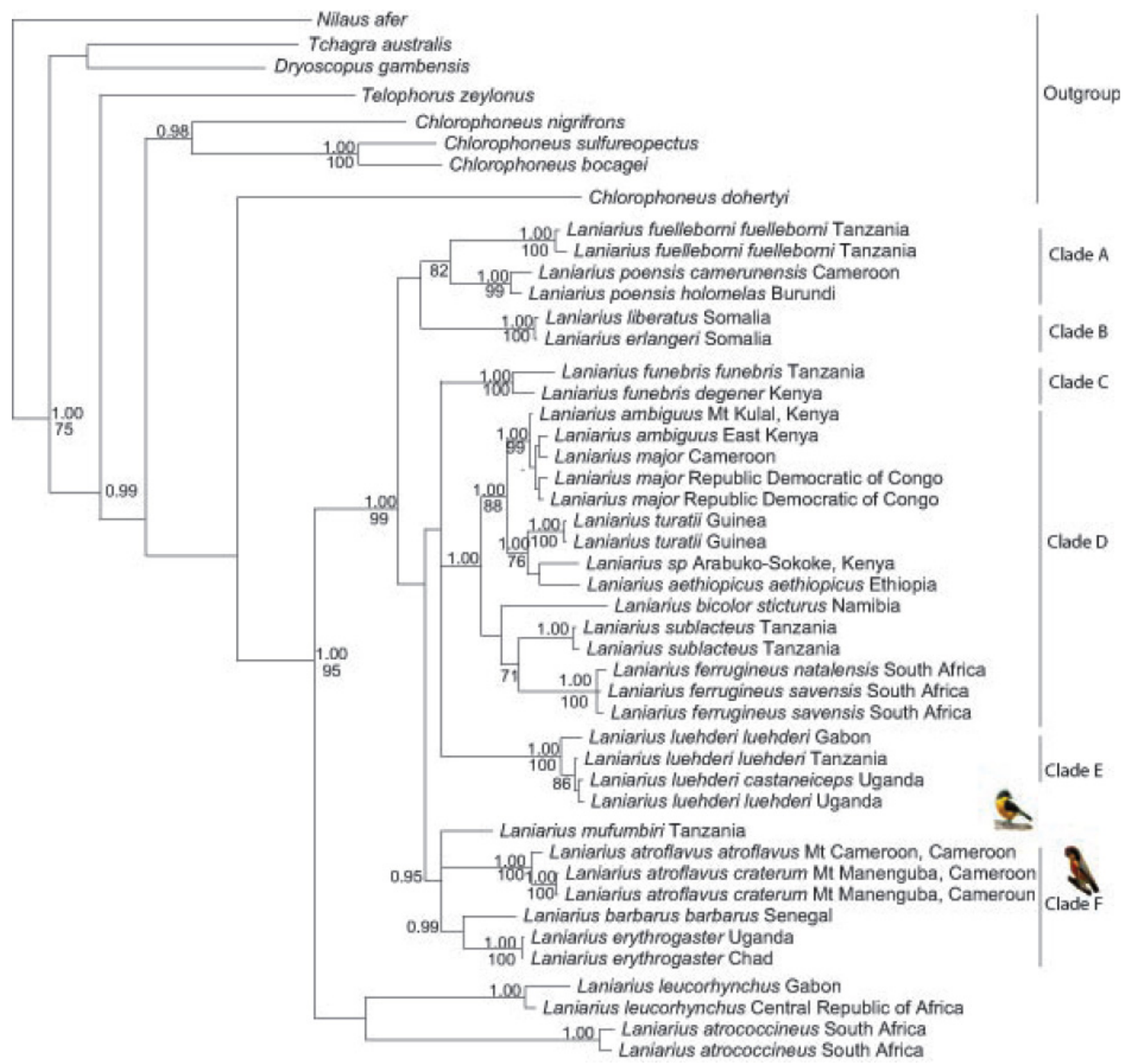

Fig. (4). Pictures of Laniarius atroflavus and Laniarius craterum on the ATPase6 tree obtained in [1] supporting the strong divergence between individuals of Cameroon Mountain and Manenguba Mountain.

The genus Laniarius comprises exclusively sedentary birds. According to [25], these birds rarely disperse more than a few kilometres from their natal sites contrary to migratory birds which have great dispersing abilities and can thus, disperse very far from their natal sites. For these sedentary birds, Highlands' forests, oceans, seas and sometimes a very long river constitute geographic barriers [23]. Based on our results, the genetic structure and the diversity within individuals of the species Laniarius atroflavus between West (Cameroon Mountain) and West (Manenguba Mountain) African parts appear to occupy distinct biotopes (Fig. 2, Tables $2,3 \mathbf{a}$ and $\mathbf{3 b}$ ). Thus, we note a clinal size variation between individuals of the Laniarius atroflavus craterum (Manenguba Mountain, having greater mensurations) in relation to Laniarius atroflavus atroflavus (Cameroon Mountain, having smaller mensurations) and this clinal size variation is emphasized on individuals gazed at Oku Mountain (Billy Nguembock, personal observations). We also notice that sometimes the separation between some CVL Mountains is not strict but if a secondary contact occurs between populations of Laniarius atroflavus of the Bamenda Highlands as well as Manenguba Mountain and those of Cameroon Mountain, we think that it will certainly lead to reinforcement particularly with the clinal size variation, mensurations as well as the variation of the color of their breast and belly (Billy Nguembock, personal observations).

The speciation process, which began, is highlighted by the different genetic structure noted between individuals of the two subspecies of the Yellow-breasted Boubou of the West (L.a. atroflavus) and the West (L. a. craterum) African parts. Thus, with only two mitochondrial markers used, we found a total of 34 different molecular characters between these two subspecies of the species Laniarius atroflavus (Tables 3a and $\mathbf{3 b}$ ). It is widely known that mutations are the raw materials of evolution. They play a primordial role in the speciation as well as can constitute a great indicator; usually these mutations are those that can be passed on to offspring. 


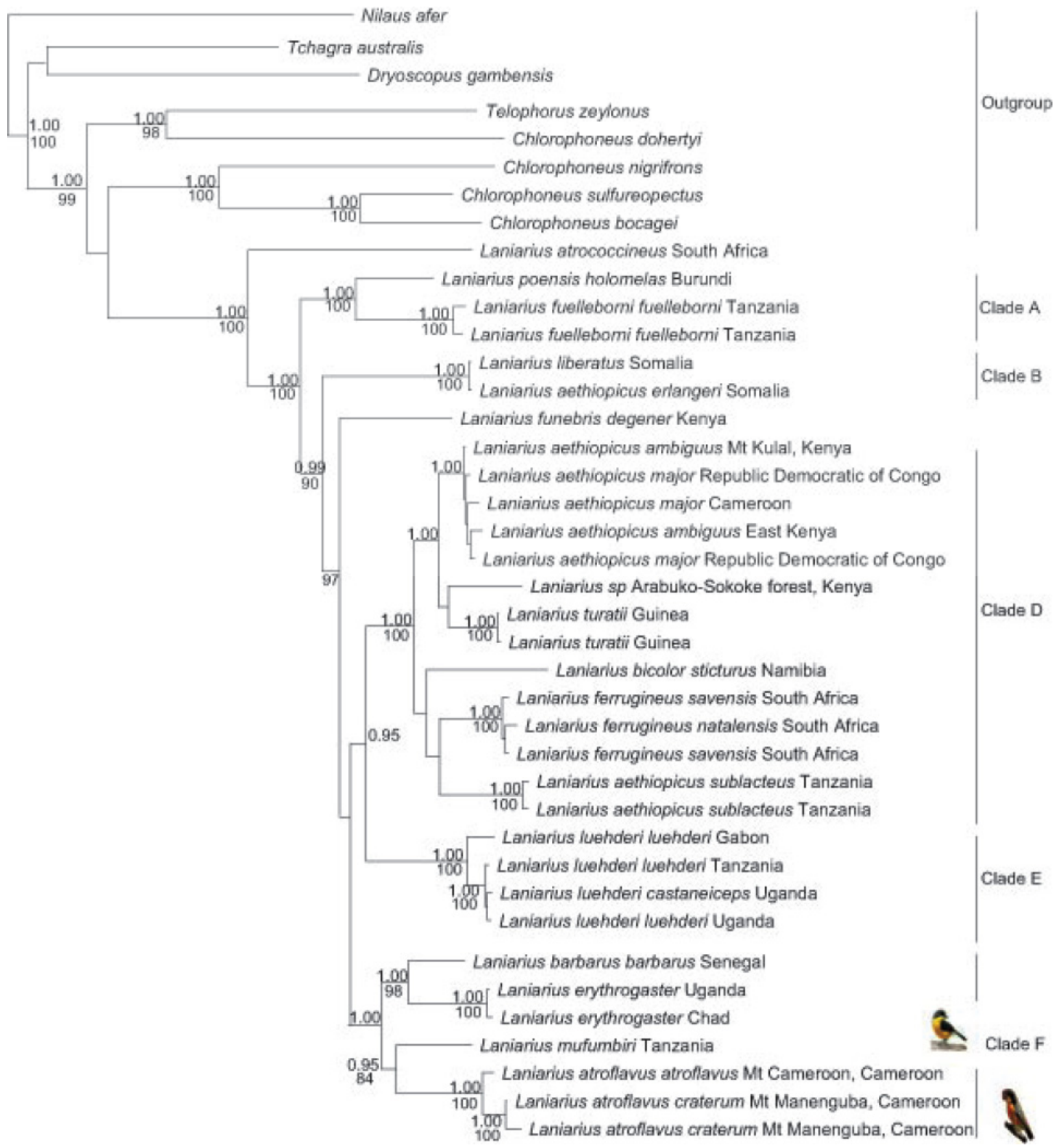

Fig. (5). Pictures of Laniarius atroflavus and Laniarius craterum on the combined dataset tree obtained in [1] confirming the strong divergence between individuals of Cameroon Mountain and Manenguba Mountain.

Thus, for instance in order to highlight the northern and southern lineages of the medaka Oryzias latipes after the estimate of their divergence, [26] set a method which permitted to find several accumulated mutations since this divergence time which indicate a strict genetic separation between the two medaka populations. Thus, the mutational differentiation observed between these two subspecies of the Yellow-breasted Boubou appears as the occurrence of the parapatric speciation which certainly evolved in some cases towards a vicariant speciation between populations of these two sedentary subspecies with a stop of recurrent gene flow which is clearly revealed by their clinal size variation, mensurations as well as the variation of the color of their breast and belly.

We think that the use of several individuals of the populations of these two subspecies of the Yellow-breasted Boubou would have been better but we are confident that this would have not greatly altered our biogeographic as well as mutational results for which our phylogenetic results have already been published [1] because the genetic structure as well as the diversity within individuals of the Western (Cameroon Mountain) and Western (Manenguba Mountain) African populations of the species Laniarius atroflavus is highlighted in this study (Figs. 3, 4 and 5 and Tables 2, 3a and $\mathbf{3 b}$ ).

\section{Taxonomic Revision}

A significant result of our study is the parapatric speciation which certainly evolved in some cases towards a vicariant speciation of the two subspecies of the Yellow-breasted Boubou highlighted in this study. For a long time, these two taxa were regarded as same species $[2,3,6]$, based on overall similarity in shape and pattern but probably also reflecting limited information on these two subspecies. For in- 
stance no earlier molecular study included all these two subspecies before our first study concerning the genus Laniarius [1]. We can now conclude that morphological similarities between these two sedentary birds have been of course acquired in their common ancestor but no enough now to characterize these two distinct taxa.

Leaning on our biogeographic and mutational results in this study and morphological differences, we suggest resurrecting names concerning the current name of Laniarius atroflavus:

Laniarius atroflavus Shelley, 1887; this taxon has been initially described as Laniarius atroflavus Shelley, 1887, from specimen collected at Cameroon Mountain. Afterwards, another taxon, Laniarius atroflavus craterum Bates, 1926, has been described from specimen obtained in the Oku Mountain. According to [27] as well as my personal observations on specimens of the Cameroon, Manenguba and Oku Mountains, morphologically, Laniarius atroflavus craterum is distinctly darker and greater than Laniarius atroflavus atroflavus. For instance whereas populations of the Cameroon Mountain have the breast and the belly with a blazing yellow, those of the Manenguba Mountain but especially those of the Oku Mountain have the breast and the belly with a very dull yellow. In Laniarius atroflavus atroflavus, wings measure 78-84 $\mathrm{mm}$ in males and 79-81 $\mathrm{mm}$ in females whereas in Laniarius atroflavus craterum, wings measure $90 \mathrm{~mm}$ in the male caught and $85-87 \mathrm{~mm}$ in females [6]. Otherwise according to this study, Laniarius atroflavus craterum Bates, 1926 appears molecularly different to Laniarius atroflavus atroflavus Shelley, 1887. For this, as in this study we include the type subspecies of the species Laniarius atroflavus and based on our results, we propose to resurrect separate names for these two distinct taxa according to our study:

1) Laniarius atroflavus Shelley, 1887, refers to Laniarius atroflavus atroflavus of the present study which has a very restricted range (Cameroon Mountain);

2) Laniarius craterum Bates, 1926, refers to Laniarius atroflavus craterum of the present study which is distributed from Manenguba Mountain and a further large study involving specimens caught in Bamenda Highlands as well as South East of Nigeria is then required to clarify their geographic range limits.

\section{CONCLUSION}

In this study, Laniarius atroflavus atroflavus of the Cameroon Mountain appear different to Laniarius atroflavus craterum of the rest of the CVL and of the South East of Nigeria. Morphologically, these two taxa appear different by the size and the coloration as already mentioned by $[6,27]$ and molecularly, estimates of the genetic distance as well as their mutational differentiation based only on two mitochondrial genes confirmed this result. For these two sedentary taxa, geological events which separated these CVL Mountains would have stopped the recurrent gene flow emphasized by their clinal size variation, mensurations as well as the variation of their coloration and even a possible secondary contact would certainly lead to reinforcement showing that the process of speciation is done. Thus leaning on our biogeographic and mutational results as well as morphologi- cal observations, we suggest resurrecting their separate names, Laniarius atroflavus Shelley, 1887 and Laniarius craterum Bates, 1926.

\section{LIST OF ABBREVIATIONS}

$\begin{array}{ll}\text { ATPase6 } & \text { ATP synthase subunit } 6 \\ \text { BI } & =\text { Bayesian Inference } \\ \text { BRM intron15 } & =\text { Brahma Protein intron-15 } \\ \text { CVL } & =\text { Cameroon Volcanic Line } \\ \text { ML } & =\text { Maximum Likelihood } \\ \text { ND2 } & =\text { NADH dehydrogenase subunit 2 } \\ \text { PP } & =\text { Posterior Probabilities }\end{array}$

\section{CONFLICT OF INTEREST}

The author confirms that this article content has no conflict of interest.

\section{ACKNOWLEDGEMENTS}

We are grateful to various researchers and institutions that caught and provided several samples or those whose sequences have been used in this study: FMNH, UMMZ, MNHN, ZMUC as well as all my new Cameroonian Southwest Region staff (Cameroon). We thank Nick Borrow for the very nice picture of Laniarius atroflavus used in this study and Alan Peterson for that of Laniarius craterum. We also thank Nik Borrow and Ron Demey for the picture of the Cameroon Volcanic Line used in this paper. We appreciate greatly several anonymous referees for their comments on an earlier version of this manuscript, particularly a few Anglophone researchers and students of the University of Yaounde I (Cameroon). We thank Christelle Leung and Philippe Lamarre of the University of Montreal for their technical support. We also thank all my staff of the Zoological research Laboratory of the University of Yaounde I (Cameroon) for their constant assistance.

\section{REFERENCES}

[1] Nguembock B, Fjeldsa J, Couloux A, Pasquet E. Phylogeny of Laniarius: molecular data reveal L. liberatus synonymous with L. erlangeri and "plumage coloration" as unreliable morphological characters for defining species and species groups. Mol Phylogenet Evol 2008; 48: 396-407.

[2] International Ornithologist Congress. The World Bird List 2012 Version 3.1. Available from: http:/www.worldbirdnames.org/nwarblers.html

[3] Hall BP, Moreau RE. An atlas of speciation in African passerine birds. London: Trustees of the British Museum (Natural History) 1970.

[4] Field GD. The Laniarius bush-shrikes in Sierra Leone. Bull Brit Orn Club 1979; 99: 42-4.

[5] Harris T, Franklin K. Shrikes and Bush-Shrikes including woodshrikes, helmet-shrikes, flycatcher-shrike, philentomas, batises and wattle-eyes. Christopher Helm: London 2000.

[6] Fry $\mathrm{CH}$, Keith S, Urban EK. The birds of Africa. Vol. 6. London: Academic Press 2000.

[7] Sayers EW, Barrett T, Benson DA, et al. Database resources of the National Centre for Biotechnology Information. Nucl Aci Res 2011; 39: D38-51.

[8] Kumar S, Tamura K, Nei M. MEGA3: Integrated software for molecular evolutionary genetics analysis and sequence alignement. Brief Bioinform 2004; 5: 150-63. 
[9] Gene Codes Corporations. Sequencher. Version 3.1. Ann. Arbor, MI 1998.

[10] Moreau RE. The bird faunas of Africa and its islands. New York and London: Academic Press 1966; p. 8.

[11] Fitton JG, Dunlop HM. The Cameroon line, West Africa, and its bearings on the origin of oceanic and continental alkali-basalt. Ear Planet Sci Lett 1985; 72: 23-38.

[12] Marzoli A, Renne PR, Piccirillo EM, et al. Silicic magmas from the continental Cameroon Volcanic Line (Oku, Bambouto and Ngaoundere): ${ }^{40} \mathrm{Ar}-{ }^{39} \mathrm{Ar}$ dates, petrology, $\mathrm{Sr}-\mathrm{Nd}-\mathrm{O}$ isotopes and their petrogenetic significance. Contrib Mineral Petrol 1998; 135: $133-50$.

[13] Ubangoh RU, Pacca IG, Nyobe JB. Palaeomagnetism of the continental sector of the Cameroon Volcanic Line, West Africa. Geophys J Inter 1998; 135: 362-74.

[14] Marzoli A, Piccirillo EM, Renne PR, et al. The Cameroon Volcanic Line revisited: petrogenesis of continental basaltic magmas from lithospheric and asthenospheric mantle sources. J Petrol 1999; 41: 87-109.

[15] Dongmo AK, Wandji P, Pouclet A, et al. Evolution volcanologique $\mathrm{du}$ Mont Manengouba (Ligne du Cameroun); nouvelles données pétrographiques, géochimiques et géochronologiques. Ear Planet Sci 2001; 333: 155-62.

[16] Burke K. Origin of the Cameroon line volcano-capped swells. J Geol 2001; 109: 349-62.

[17] Kamgang P, Njonfang E, Chazot G, Tchoua F. Géochimie et geochronology des laves felsiques des monts Bamenda (ligne volcanique du Cameroun). Comp Rend Geosci 2007; 339: 659-66.
[18] Fitton JG. The Benue trough and Cameroon line: a migrating rift system in West Africa. Ear Planet Sci Lett 1980; 51: 132-8.

[19] Morgan WJ. Hotspot tracks and the early rifting of the Atlantic. Tectonophysics 1983; 94: 123-39.

[20] Stuart GW, Fairhead JD, Dorbath L, Dorbath C. Crustal structure of the Adamawa plateau Cameroon. Rev Sci Et Tech Ser Sci Terre 1985; 1: 1-2.

[21] Dorbath C, Dorbath L, Fairhead JD, Stuart GW. A teleseismic delay time study across the Central African Shear Zone in the Adamawa region of Cameroon, West Africa. Geophys J R Astr Soc 1986; 86: 751-66.

[22] Déruelle B, Ngounouno I, Demaiffe D. The 'Cameroon Hot Line' CHL: a unique example of active alkaline intraplate structure in both oceanic and continental lithospheres. Comp Rend Geosci 2007; 339: 589-600.

[23] Nguembock B. Etude phylogénétique et biogéographique de l'avifaune forestière des montagnes de l'Ouest Cameroun. PhD Thesis. University of Paris VI: France 2008.

[24] Fuchs J, Fjeldsa J, Pasquet E. An ancient African radiation of corvoid birds (Aves: Passeriformes) detected by mitochondrial and nuclear sequence data. Zool Scr 2006; 35: 375-85.

[25] Borrow N, Demey R. Field Guide to the Birds of Western Africa. Christopher Helm: London 2004.

[26] Takeda H. Draft genome of the medaka fish: a comprehensive resource for medaka developmental genetics and vertebrate evolutionary biology. Dev Growth Differ 2008; 50 (Suppl 1): S157-66.

[27] Bates GL. New birds from the mountains of N.W. Cameroon. Bull Brit Orn Club 1926; 46: 88-9.

Received: March 13, 2014

Revised: May 31, 2014

Accepted: June 09, 2014

(C) Billy Nguembock; Licensee Bentham Open.

This is an open access article licensed under the terms of the Creative Commons Attribution Non-Commercial License (http://creativecommons.org/licenses/by-nc/3.0/) which permits unrestricted, non-commercial use, distribution and reproduction in any medium, provided the work is properly cited. 